\title{
Theoretical Study of the Electronic Properties of Nickel Clusters
}

\author{
Y. Benkrima ${ }^{1,2^{*}}$ \\ ${ }^{1}$ Ecole Normale Supérieure de Ouargla, Algeria \\ ${ }^{2}$ Laboratoire de Développement des Energies Nouvelles et Renouvelables en Zones Aride, Univ Ouargla, \\ Faculté de Mathématiques et des Sciences de la Matière, 30000 Ouargla, Algeria
}

(Received 07 August 2020; revised manuscript received 18 December 2020; published online 25 December 2020)

\begin{abstract}
Low-energy geometry and electronic structures of nickel $\left(\mathrm{Ni}_{n}\right)$ clusters, where the number of atoms $n$ constituting these clusters ranges from 2 to 10, have been obtained based on density functional theory (DFT) with the use of Generalized Gradient Approximation (GGA) taken from SIESTA method. By searching for clusters with low-energy structures, new structures with low-energies were obtained. For each cluster size, the average bond length, binding energy, HOMO-LUMO gap, second difference in energy, Vertical Ionization Potential (VIP), adiabatic ionization potential (AIP) and finally the Density of States (DOS) were calculated by this method. Low-energy structures of clusters are even for values $n \leq 6$, while stability showed that the cluster $\mathrm{Ni}_{10}$ has the highest value of the binding energy. The VIP, AIP and HOMO-LUMO gap show clear oscillations at odd and even values, indicating that $\mathrm{Ni}_{2,4,6,8,10}$ clusters have a higher stability compared to their neighboring clusters. The second difference in energy shows and confirms the stability of the aforementioned clusters. The results also show the DOS of the clusters studied near the Fermi level and the relation of oscillation behavior witnessed by odd and even clusters in the number of atoms with their stability. In this research, I succeeded in studying some clusters of nickel $\mathrm{Ni}_{n}$ using DFT, tackling their structural aspects as well as their electronic properties.
\end{abstract}

Keywords: Density functional theory, Cluster, Nickel, Electronic structure, Electronic properties.

DOI: 10.21272/jnep.12(6).06013

PACS number: 36.40.Cg

\section{INTRODUCTION}

In recent years, the interest in studying metal clusters has intensively increased. This is due to the development of experimental and theoretical techniques that help to conduct in-depth studies of this type of systems. The clusters of transition metals have a particular interest, and this is due to their potential use in many areas, such as catalytic processes, mineral chemistry, organic matter, or new nanoelectronic materials.

These clusters are sensitive and changeable, depending on the number of constituent atoms. They can also change significantly if one atom of these clusters is added or removed, and so they become completely different from the properties of the material and are in bulk condition. Clusters are classified as nanoparticles provided that their size is between 1 and $100 \mathrm{~nm}$ which is the volume between molecules and bulk material.

Because of the electronic structure that nickel $\mathrm{Ni}$ has $[\mathrm{Ar}] 3 d^{9} 4 s^{1}$, when a single electron is outside the shell $(d)$, a slight difference in energy between the atomic levels ( $d$ and $s$ ) leads to a strong hybridization action that plays a major role in distinguishing nickel clusters with unique electronic structures and properties. Clusters of noble metals can also be used within a wide range in many technological fields due to their catalytic, magnetic and electronic properties [1, 2].

In the last few years, the study of structures of nickel $(\mathrm{Ni})$ clusters and their properties has received great attention in both theoretical and experimental terms. Several variables and electronic, optical and magnetic properties have been experimentally and theoretically demonstrated [3-8].
Optimal electronic structures for clusters cannot be reached except by comparing the obtained experimental results along with the presented theoretical predictions [9-11], the theoretical analysis used for the DFT is still not clearly explored in this field. Actually, the study of DFT is classified into three sections, namely, theoretical, conceptual and computational study.

In this research, I succeeded in studying some clusters of nickel $\mathrm{Ni}_{n}$ using DFT, tackling their structural aspects as well as their electronic properties. The results were very interesting indeed.

\section{COMPUTATIONAL DETAILS}

In this research, I established the calculations on the principles of spin-polarized density-functional theory (DFT) $[12,13]$. In terms of exchange and correlation functional, the Generalized Gradient Approximation (GGA) functional was applied according to the suggestions of Perdew, Burke and Ernzerhof (PBE) [14]. The increase in geometries of clusters was made through functional density first principle-simulations technique, which is rooted in the numerical atomic orbital method according to SIESTA code implementation [15, 16]. The clusters' structures were also confirmed by using the MATERIAL STUDIO software code [17]. Extended wave functions took place in plane-wave basic groups using a kinetic energy cutoff of $300 \mathrm{eV}$. This was applied to all systems included in our research. Monkhorst-Pack grid having special $k$-point meshes was used to carry out the integrations of Brillouin zone. In terms of implementing self-consistent field calculations, the convergence criterion of $10^{-4}$ on to the total energy was

\footnotetext{
*b-amina1@hotmail.fr
} 
used for this purpose. Actually, $0.05 \AA$ was the value of the maximum tolerance for ion displacement in the cluster. I obtained the optimized structures when the atomic forces were less than $0.005 \mathrm{eV} / \AA$. Geometric optimizations have been initiated from many primary candidate geometries, which range from the openstructured arrangement of $\mathrm{Ni}$ atoms to the close-packed one. Z-matrices in the Q-Chem program output provided the optimized electronic structure for each cluster. However, I calculated electronic properties based on both self-consistent field (SCF) total electronic energy and orbital energy values. I use total energies of the most stable clusters to find out their bonding energy, vertical ionization potential (VIP), HOMO-LUMO energy gap, second difference in energy, density of state (DOS) as they are functions helping in determining the cluster stability.

\section{RESULTS AND DISCUSSION}

\subsection{Geometrical Structures}

In Table 1, I present a summary of the average bonding lengths of $\mathrm{Ni}_{n}$ clusters, where $n=2-10$. After obtaining the most stable structures for nickel $\mathrm{Ni}_{n}$ clusters, we studied in depth each obtained cluster. In Fig. 1, I show the most stable structures in this study, using SIESTA program based on DFT.

For $\mathrm{Ni}_{2}$ cluster, its average bond length is estimated to be $2.374 \AA$. Actually, this result is close to theoretical results of Basch et al. and Mlynarsky et al. [18, 19] and experimental results of the average bond length in the work quoted in Ref. [20].

Various values of the average bond length of clusters $\mathrm{Ni}_{n}$ where $n=2-10$ are shown in Fig. 2 . For the clusters of $\mathrm{Ni}_{n}$ where $n=2-6$, they are either linear or closed chains in the plane, with an average bond length estimated as $2.373 \AA$, 2.408 $\AA$, $2.413 \AA$, $2.505 \AA, 2.518 \AA$, respectively. Generally, it is observed that the average bond length increases with the cluster size.

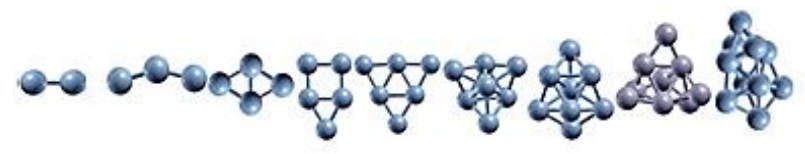

Fig. 1 - The lowest energy structures of $\mathrm{Ni}_{n}(n=2-10)$ clusters

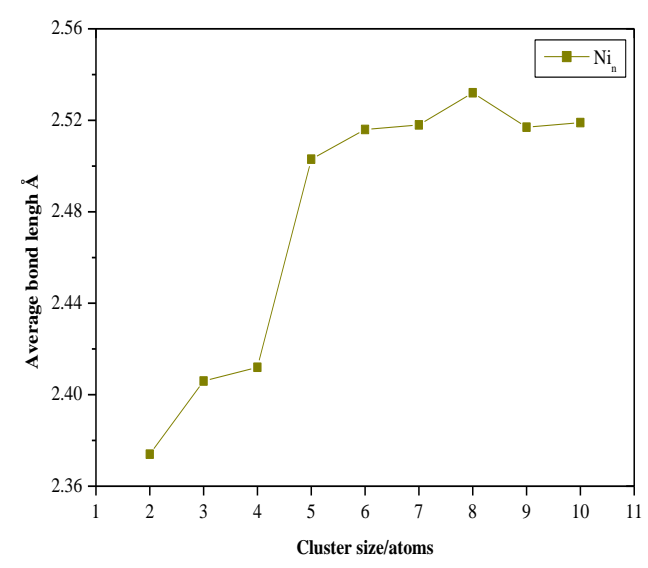

Fig. 2 - Average bond lengths for $\mathrm{Ni}_{n}$ clusters
Based on the results shown in Fig. 2, I conclude that the values of the average bond length increase in parallel with the increase in the cluster size. This is due to the fact that the ratio of atoms on the surface of the cluster is greater than the ratio of atoms in the core of it. In fact, because they are less compact, they cause the increase in the bond length. These results are somewhat compatible with theoretical and experimental results of Lathiotakis et al. [20].

\subsection{Electronic Properties}

One of the most important physical factors that are to be studied in materials and clusters physics is the binding energy (cohesion). It shows the stability of clusters obtained by comparing the result of their binding energy to other previous results for the same metal clusters. On this purpose, I use the following equation, which is related to the cluster energy and the energy of atoms constituting the cluster being alone:

$$
E_{B}=\frac{E_{T}-n E_{a t o m}}{n}(\mathrm{eV})
$$

where $E_{T}$ is the total electronic energy of the cluster; $E_{\text {atom }}$ is the total electronic energy of the atom being alone.

The results obtained are included in Fig. 3 below. In this figure, I highlight the binding energies of nickel $\mathrm{Ni}_{n}$ clusters, where $n=2-10$.

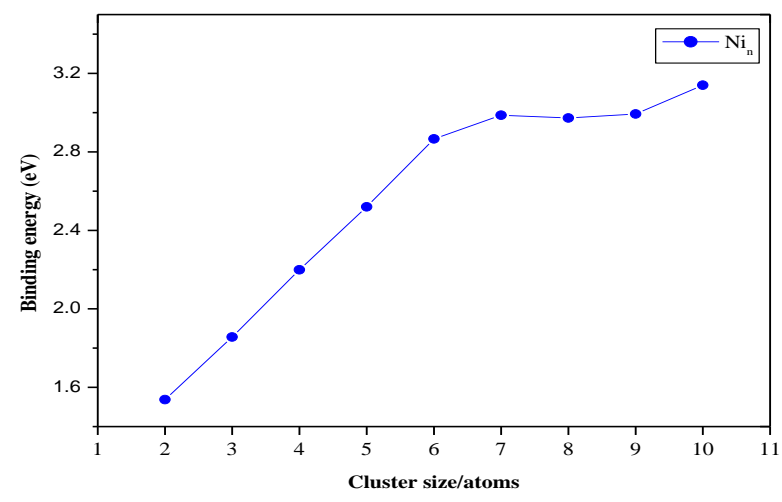

Fig. 3 - Binding energies per atom for $\mathrm{Ni}_{n}$ clusters

It is clear that the binding energy increases with the increase in the cluster size. This explains the stability of major clusters constituting the materials during their construction processes. It is noticed in Fig. 3 that the cluster $\mathrm{Ni}_{10}$ is the most stable compared to the remaining clusters. These results are quite similar to the results in Ref. [20].

Another variable of equal importance, which is equivalent to a gap in materials, is HOMO-LUMO gap. It is the difference in energy between the highest occupied orbit and the lowest unoccupied orbit in the spectrum of cluster energy levels. It shows the stability of clusters, as well as their interaction. Also, my calculations were carried out in the case of spin polarization. This provided me with two gaps for every studied cluster. Then I made the difference between them, hence I obtained the real gap for each cluster.

The obtained results illustrated in Fig. 4 show that 
the cluster $\mathrm{Ni}_{2}$ has the highest value, i.e. it has great stability. This means that we need tremendous energy to transfer an electron from HOMO to LUMO region; that is why it is widely used in the nano-field.

As I saw previously in the results of HOMO-LUMO gap, I calculated the second difference in energy $\Delta_{2} E(n)$ as shown in Fig. 5.

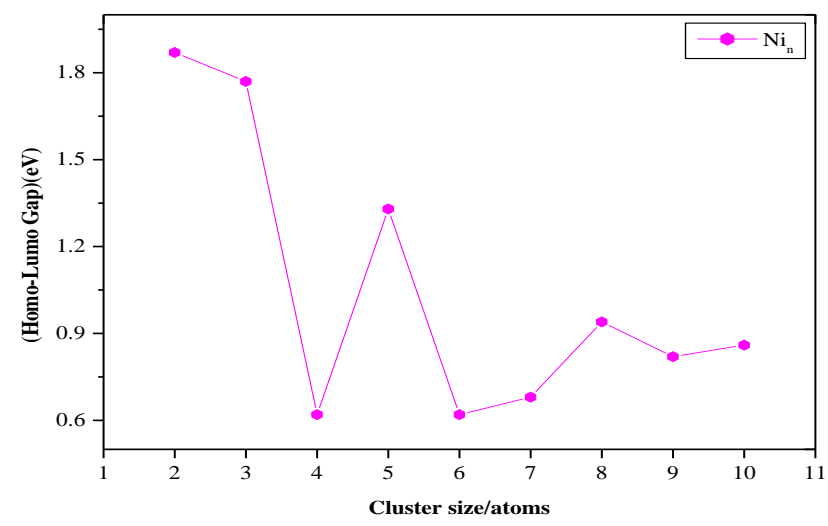

Fig. 4 - HOMO-LUMO gap for $\mathrm{Ni}_{n}$ clusters

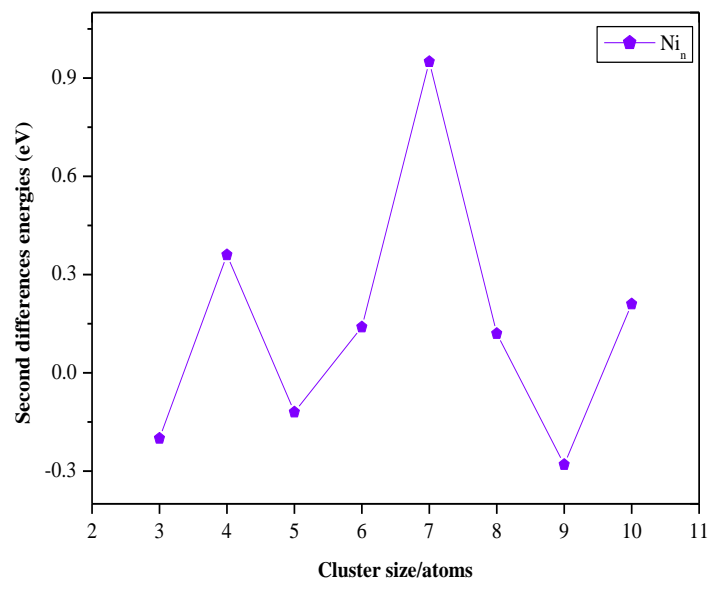

Fig. 5 - Second difference in energy $\Delta_{2} E(n)$ for $\mathrm{Ni}_{n}$ clusters

In the field of clusters, there is another significant variable that is calculable, through which I know the stability of the clusters obtained and compare them to each other. Actually, the more this values in the cluster increases, the greater the stability. This is given by the following equation:

$$
\Delta_{2} E(n)=E_{(n+1)}+E_{(n-1)}-2 E_{(n)},[
$$

where $E_{(n+1)}, \square E_{(n-1)}, E_{(n)}$ are energies of clusters having the size $(n+1),(n-1),(n)$, respectively.

According to the results, it was noticed that all clusters have a positive value, except for the clusters $\mathrm{Ni}_{3}$ and Nig. In addition, the cluster $\mathrm{Ni}_{7}$ is more stable compared to the rest. However, it should be noted that the slight differences between the more and less stable clusters are not significant.

The vertical ionization potential (VIP) is used to determine the chemical stability of small clusters as the proportion between the size of the cluster and its stability is inverse, meaning that the greater the size of the cluster, the less its chemical activity, and thus its stability.
The amount of energy required to deliver the system ions to the lowest levels of vibration, called adiabatic ionization potential (AIP), has been calculated. We see in Fig. 6 that a decrease in the values of the VIP has been recorded and this is by increasing the volume. This means that it facilitates the extraction of an electron in larger systems (which have more atoms). Thus, this system is considered to be the least stable.

I have noticed the existence of peaks at each of $\mathrm{Ni} n$ clusters, where $n=2,4,6,8,10$. We can consider them more stable clusters compared to their neighbors; this result is close to theoretical results and experimental results of the ionization.

Also, the AIP in cluster physics shows the nature of the formed bonds of clusters. When weak values are recorded in the clusters (Fig. 7), it becomes clear that when approaching the metal state, the AIP values decrease with increasing cluster size. This means that when we process bigger clusters we move to the metallic properties of these systems. Adding to that, a greater value has been recorded in $\mathrm{Ni}$, which can be considered more stable compared to the remaining clusters.

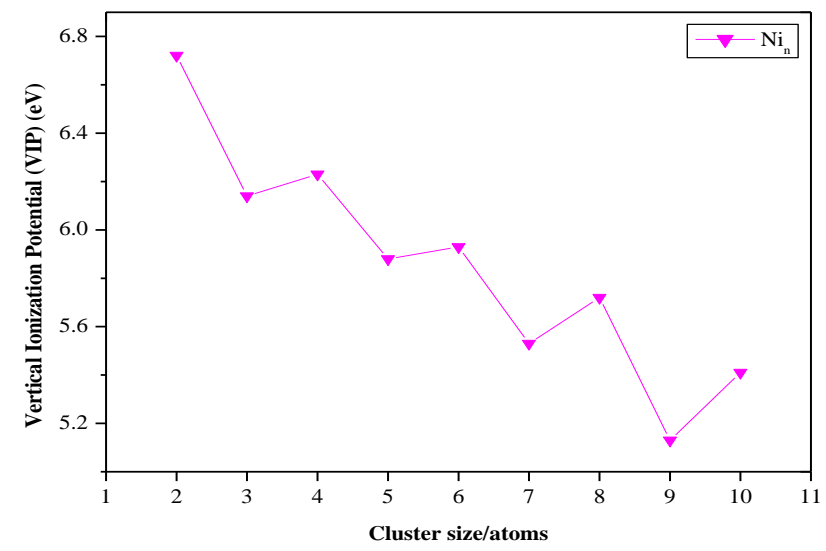

Fig. 6 - Ionization potential for $\mathrm{Ni}_{n}$ clusters

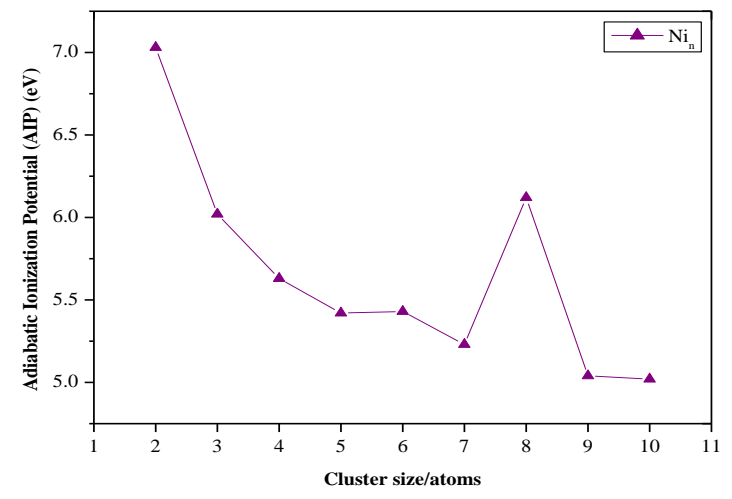

Fig. 7 - AIP for $\mathrm{Ni}_{n}$ clusters

The density of states (DOS) provides us with a general explanation of the electronic structures of these clusters. For example, I find that the chemical activity of some clusters is closely related to the density of electrons located near the Fermi level $\left(E_{F}\right)$. The more DOS in this region, the greater the chemical activity of the cluster. In this research, I looked for electronic properties, specifically for the DOS for all obtained clusters $\mathrm{Ni}_{n}$ where $n=2-10$, as shown in Fig. 8 . 


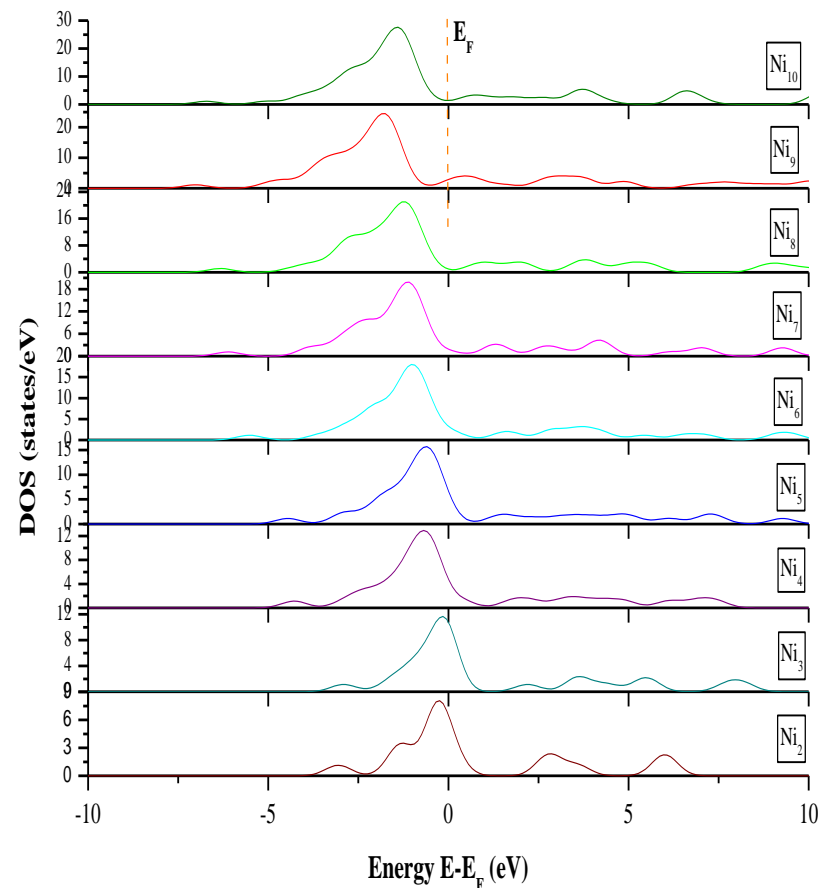

Fig. 8 - DOS for $\mathrm{Ni}_{n}$ clusters

In Fig. 8, I present a comparison between all the most stable $\mathrm{Ni}_{n}$ clusters. It is observed that the upper peaks of DOS near the Fermi level of the $\mathrm{Ni}_{2}$ and $\mathrm{Ni}_{3}$ clusters extend in the range $0.2 \div-0.9 \mathrm{eV}$, while $\mathrm{Ni} 4$ and $\mathrm{Ni}_{5}-$ in the range $-0.25 \div-0.52 \mathrm{eV}$. Concerning $\mathrm{Ni}_{6}, \mathrm{Ni}_{7}$ and $\mathrm{Ni}_{8}$, they are limited to $-1.70 \div-1.80 \mathrm{eV}$. The cluster Nig has the highest peaks of its DOS concentrated in the energy field $-1.25 \div-1.46 \mathrm{eV}$, while peaks of DOS of the $\mathrm{Ni}_{10}$ cluster are limited to the field $-1.15 \div-1.32 \mathrm{eV}$. It is very noticeable in Fig. 8 that the $\mathrm{Ni}_{2}$ cluster has a very high electronic density at the Fermi level $(0 \mathrm{eV})$, followed by the $\mathrm{Ni}_{3}$ cluster with a slight difference and then the $\mathrm{Ni}_{5}$ and $\mathrm{Ni}_{4}$ clusters. The remaining clusters recorded low peaks of DOS at this level.

Based on this analysis, I can expect that the clusters $\mathrm{Ni}_{2}$ and $\mathrm{Ni}_{3}$ are the most chemically active with selective activation energy. This corresponds to an energy distance that is far from the Fermi level. They have a distinctive feature that enables them to work in the field of stimulation for instance, and these results are also compatible with ionization energy results.

\section{CONCLUSIONS}

To sum up, the calculated structural and electronic properties of nickel $\mathrm{Ni}_{n}$ clusters, where $n=2$-10, were obtained based on the DFT and GGA. This led us to important conclusions regarding their properties. Actually, I found out that clusters with less than 6 atoms are structures in the plane; these results are very similar to those in previous studies. Besides, the second difference in energy showed that the clusters $\mathrm{Ni}_{n}$ where $n=2,4,6,8,10$ are the most stable compared to their neighbors; and the binding energy in general increases compared to the decrease in the ionization potential and this is due to the increase in the size of the cluster. The HOMO-LUMO gap showed oscillations in values of the odd and even clusters. Finally, the results of DOS confirmed that the clusters $\mathrm{Ni}_{n}$ where $n=2,3$ are so important to be used in nanostructures as they have very high chemical activity.

\section{REFERENCES}

1. T. Xiaowei, Q. Wang, L. Ping, H. Weiqiang, I. Anatoly, W. Frenkel, M. Nebojsa, C. Jonathan Hanson, J.A. Rodriguez, J. Am. Chem. Soc. 130, 1093 (2008).

2. R. Ferrando, J.R. Jellinek, L. Johnston, Chem. Rev. 108, 845 (2008).

3. Mottura, R.T. Wu, M.W. Finnis, R.C. Reed, Acta Materialia 56, 2669 (2008).

4. B. Debashis, S. Prasenjit, J. Phys. Chem. A 114, 1835 (2010).

5. V. Grigoryan, S. Michael, Phys. Rev. B 70, 205415 (2004).

6. B.K. Rao, P. Jena, J. Chem. Phys. 117, 5234 (2002).

7. K. Ajay, K. Seungkoo, A. Carlos Larriba, O. Hui, Nanotechnology. 25, 385601 (2014).

8. Y.H. Yaoa, X. Gu, M. Ji, X.G. Gong, W. Ding-sheng, Phys. Lett. A 360, 629 (2007).

9. V. Bonačić-Kouteck, J. Burda, R. Mitrić, M. Ge, G. Zampella, P. Fantucci, J. Chem. Phys. 117, 3120 (2002).

10. H.M. Lee, M. Ge, B.R. Sahu, P. Tarakeshwar, K.S. Kim, J. Phys. Chem. B 107, 9994 (2003).

11. G.F. Zhao, Z. Zeng, J. Chem. Phys. 125, 014303 (2006).

12. D. Ruibin, C. Xiaoshuang, Z.Huxian, W. Xiaofang, S. Haibo, D Zonglin, W. Lu, J. Phys. B: At. Mol. Opt. Phys. 44, 035102 (2011).

13. U.G. Gabriel, A.C. Reber, S.N. Khanna, New. J. Chem. 37, 3928 (2013).

14. Y. Benkrima, A. Ouahab, Der Pharma Chemica. 9, 62 (2017).

15. J.M. Soler, R.B. Marcela, M. Karo, L.G. Ignacio, O. Pablo, S.P. Daniel, A. Emilio, Phys. Rev. B 61, 5771 (2000).

16. J.M. Soler, E. Artacho, J.D. Gale, A. Garci'a, J. Junquera, P Ordejo'n, D. Sa'nchez-Portal, J. Phys. Condens. Matter. 14, 2745 (2002).

17. Accelrys Material Studio 7.0.

18. Satyender Goel, Artem E. Masunov, J. Mol. Model. 18, 783 (2012).

19. G. Aram, S. Darioush Harafie, Int. J. New Chem. 5, 188 (2018).

20. G. Etienne, K. Amit, B. Etienne, R. Laurent, M. Laurence, J. Yves, Phys. Rev. B 86, 054116 (2012). 


\title{
Теоретичне вивчення електронних властивостей нікелевих кластерів
}

\author{
Y. Benkrima ${ }^{1,2}$ \\ ${ }^{1}$ Ecole normale supérieure de Ouargla, Algeria \\ ${ }^{2}$ Laboratoire de Développement des Energies Nouvelles et Renouvelables en Zones Aride, Univ Ouargla, \\ Faculté de Mathématiques et des Sciences de la Matière, 30000 Ouargla, Algeria
}

Низькоенергетичні та електронні структури кластерів нікелю $\left(\mathrm{Ni}_{n}\right)$, де кількість атомів $n$, що складають ці кластери, коливаеться від 2 до 10, отримані на основі функціональної теорії густини (DFT) з використанням узагальненого наближення градієнта (GGA), взятого з методу SIESTA. Шляхом пошуку кластерів з низькоенергетичними структурами були отримані нові структури з низькими енергіями. Для кожного розміру кластера цим методом розраховували середню довжину зв'язку, енергію зв'язку, зону НОMO-LUMO, другу різницю в енергії, вертикальний потенціал іонізації (VIP), адіабатичний потенціал іонізації (AIP) i, нарешті, густину станів (DOS). Низькоенергетичні структури кластерів є парними для значень $n \leq 6$, в той час як стабільність показала, що кластер $\mathrm{Ni}_{10}$ має найвище значення енергії зв'язку. VIP, AIP та зона HOMO-LUMO демонструють чіткі коливання при непарних і парних значеннях, що вказуе на те, що кластери $\mathrm{Ni}_{2,4,6,8,10}$ мають вищу стабільність порівняно з сусідніми кластерами. Друга різниця в енергії показуе і підтверджуе стабільність згаданих кластерів. Результати також показують DOS кластерів, що вивчались, поблизу рівня Фермі та зв'язок коливальної поведінки непарних і парних (за числом атомів) кластерів з їхньою стабільністю. У статті вдалося вивчити деякі кластери нікелю $\mathrm{Ni}_{n}$ за допомогою DFT, розглядаючи їх структурні аспекти, а також електронні властивості.

Ключові слова: Функціональна теорія густини, Кластер, Нікель, Електронна структура, Електронні властивості. 